\title{
PSYCHE
}

VOL. 58

MARCH, 1951

No. 1

\section{ON SOME CENTRAL AND SOUTH AMERICAN PTEROSTICHINI (COLEOPTERA, CARABIDAE) IN THE MUSEUM OF COMPARATIVE ZOOLOGY*}

By S. L. Straneo

Gallarate, Italy

Some weeks ago I received for study from Dr. P. J. Darlington Jr. many undetermined Central and South American Pterostichini from the collection of the Museum of Comparative Zoology of Cambridge, Massachusetts. This material was so interesting that I decided to write the present notes on it and on a few examples of two of the same species in my collection. I have to thank Dr. Darlington for submitting these specimens to me and for permission to keep many duplicates for my collection.

\section{Tichonia orientalis, $\mathrm{n}$. sp.}

Purplish violaceous, metallic color stronger in the holotype $o$ than in the allotype $\&$; lower surface blackish, legs dark rufopiceous, antennae and palpi wholly ferrugineous. Length $11.6 \mathrm{~mm}$.; width $4.4 \mathrm{~mm}$. Head robust; eyes prominent and convex; frontal impressions wide and deep, narrow and strongly divergent behind, reaching the 2 nd supraorbital seta; antennae long and slender, exceeding by the last three segments the base of the pronotum. Prothorax transverse in the of $(2.5$ by $3.3 \mathrm{~mm}$.) and nearly square in the $q$; sides rather strongly rounded and narrowed to apex $(2 \mathrm{~mm}$.), straight or a little subsinuate towards base $(2.8 \mathrm{~mm}$.) ; anterior angles obtuse, rounded; basal angles nearly square, with apices slightly rounded; basal impressions, one on each

"Published with a grant from the Museum of Comparative Zoology at Harvard College 
side, deep, wide, more than one half the length of the prothorax; space between the basal impressions and the sides strongly sloping towards the impressions; lateral margin narrow, with the two usual setiferous punctures; base impunctate, unmargined, nearly straight; disc very depressed, with the median line deeply impressed, elongate, reaching the base, not reaching the anterior margin. Elytra oval (7.4 by $4.4 \mathrm{~mm}$.), strongly convex; shoulders square, each with a distinct tooth; basal margin strong, nearly straight; striae deep, impunctate; interstices strongly convex, base of the second with an umbilicate pore, third without dorsal punctures, sixth and seventh a little raised near the shoulders; apical declivity rather strong. Underside wholly impunctate; prosternum with a moderate depression before the coxae; prosternal process not margined at the extremity; metepisterna very short; abdominal segments strongly sulcate across the base; anal segment with a single puncture on each side in the $\delta$ and two in the $o$. Aedeagus with apical blade peculiarly formed (Fig. 1). Anterior tarsi of os moderately dilated.

Holotype $\hat{o}$ from Hansa Humboldt, Sta. Catharina, Brazil, in my collection (from E. Reitter) ; allotype o from Nova Teutonia $\left(27^{\circ} 11^{\prime}-52^{\circ} 23^{\prime}\right)$, 3500 m., Brazil (F. Plaumann, 20-X-1948) (Museum of Comparative Zoology, Type No. 28,441 ) .

This new species has, like T. catharinae Tschit., the base of the prothorax distinctly narrower than the base of the elytra, but the sides of the prothorax are slightly subsinuate toward the base and the size is much smaller (11.6 instead of $16 \mathrm{~mm}$.).

Tichonia paraguayensis, $n$. sp.

Purplish violaceous on prothorax and elytra; head blackish; lower surface black, shiny, a little iridescent; legs blackish; antennae and palpi dark rufopiceous. Length $15.2 \mathrm{~mm}$.; width $5.7 \mathrm{~mm}$. Head robust and strongly sculptured; eyes wide and prominent; frontal grooves rather narrow, not elongate, reaching only the anterior supraorbital puncture; antennae rather robust, exceeding the base of 
the prothorax by the two last segments. Prothorax moderately transverse (3.4 by $4.3 \mathrm{~mm}$.), with sides strongly rounded and narrowed anteriorly (width of apex $2.3 \mathrm{~mm}$.), only a little rounded and nearly straight towards base (4.1 $\mathrm{mm}$.), which is wider than base of elytra; anterior angles obtuse, rounded; basal ones raised, nearly square, not dentate; basal impressions much longer than in any other species of the genus, reaching $3 / 4$ of the length of the prothorax, very deep; lateral margin narrow, with the two usual punctures; base impunctate, strongly depressed, as is the whole disc. Elytra oblong-oval (9 by $5.7 \mathrm{~mm}$.), convex, with the sides slightly rounded behind the shoulders and widest near middle; shoulders square, dentate; striae deep, impunctate; interstices very convex, the sixth and seventh a little raised near shoulders. Prosternum with a moderate longitudinal groove; prosternal process not margined; metepisterna short; ventral segments strongly sulcate across base and with deep depressions at sides; anal segment with one fovea on each side in $\delta$ and two in $\$$. Aedeagus with apical blade rounded, without apical spine.

Holotype $\hat{o}$ and 2 ô $\hat{o}$ paratypes from Rio Confuso, Paraguay (from Institut Fabre, through Prof. Porta), in my collection; allotype o from Villarica, Paraguay ( $\mathrm{Mu}-$ seum of Comparative Zoology, Type No. 28,440).

This new species is colored like T. superba and festiva Tschit. but belongs to the group of depressicollis Dej., with the tip of the aedeagus simply rounded, without spine. It differs from every previously known species of the genus by the very long, strong basal impressions of the prothorax, which reach three fourths the length of the prothorax, while in the other species they do not exceed half the length.

\section{Oxycrepis parvula, n. sp.}

Black shining, with apex of elytra slightly brownish; antennae with segments 1-3 ferrugineous brown, 4-6 darker, 7-11 wholly white; ventral segments brownish, iridescent; anal segment ferrugineous. Length $5.6 \mathrm{~mm}$.; width $2.2 \mathrm{~mm}$. Head elongate; eyes wide, moderately convex, temples very short; frontal grooves deep, wide, short; antennae long. 
Pronotum as in the other species of the genus, nearly as long as wide (1.3 by $1.4 \mathrm{~mm}$.), with base $(0.7 \mathrm{~mm}$.) narrower than apex $(0.8 \mathrm{~mm}$. $)$; latter with a strong, entire margin; base impunctate, with sides strongly oblique, so that the basal angles are obtuse; lateral margins very narrow; disc strongly convex, with median line deeply impressed from anterior margin nearly to base. Elytra subrectangular ( 3 by $2.2 \mathrm{~mm}$.) ; shoulders widely rounded; striae deep, wide, and strongly punctate; interstices convex; striae 4-9 not reaching base of elytra. Underside impunctate; metepisterna elongate, strongly grooved inwardly; anal segment of $\delta$ with one setiferous puncture on each side.

Holotype of from Rio Frio (S. of Santa Marta), Prov. of Magdalena, Colombia (Museum of Comparative Zoology, Type No. 28, 436) ; and allotype o from Sevilla (near Rio Frio), August 28 (in my collection). Both specimens collected by P. J. Darlington Jr.

This new species is near gracilis Bts. but is less narrow, with apex of elytra darker, and with base of prothorax wholly impunctate.

Loxandrus minimus, $\mathrm{n}$. sp.

Head and pronotum brown, more or less infuscate; elytra blackish brown with humeral margins, suture, and lateral margins ferrugineous; epistoma, legs, palpi, and first three antennal segments ferrugineous, the other segments darker. Length $4.2 \mathrm{~mm}$.; width $1.8 \mathrm{~mm}$. Head normal; eyes moderately convex; frontal grooves short and wide; antennae rather long. Prothorax transverse (1 by $1.4 \mathrm{~mm}$.), slightly emarginate anteriorly, with an anterior submarginal line not interrupted at middle; sides moderately rounded, slightly subsinuate before base; anterior angles rounded, not or very little prominent; anterior margin a little narrower $(0.95 \mathrm{~mm}$.) than base $(1.2 \mathrm{~mm}$.$) ; hind angles square, with$ their apices sharp and dentate; basal impressions rather deep, moderately elongate; spaces between them and lateral margins nearly flat; lateral margins rather narrow, each with the two usual punctures; base a little depressed, not 
margined at sides, evidently punctate at middle; disc slightly convex, with median line rather deep but short. Elytra subrectangular (2.6 by $1.8 \mathrm{~mm}$.) ; sides rounded just behind shoulders, thence parallel for $3 / 4$, of length; shoulders widely rounded; striae deep and well punctate; interstices moderately convex. Underside smooth; metepisterna twice as long as wide. Hind tarsi not carinate above; onychium glabrous beneath, nearly as long as the first segment. Aedeagus as figured (Fig. 2).

Holotype $\hat{o}$ (Museum of Comparative Zoology, Type No. 28,438 ), allotype $q$ (in my collection), and one paratype (M.C.Z.) from Rio Frio (S. of Santa Marta), Prov. of Magdalena, Colombia; and 4 additional paratypes (M.C.Z. and my collection) from Aracataca (S. of Rio Frio). All specimens taken by P. J. Darlington.

L. minimus is the smallest species of the genus. The small size and the color distinguish it at once.

\section{Sierrobius, n. gen.}

Not winged; glabrous. Head with clypeus bisetose; two supraorbital setae each side; supraorbital ridges regular; labrum transverse, 6-setose; mandibles rather elongate, sharp, hooked at tip, the external scrobes without setae; mentum rather deeply incised, median tooth more or less prominent, excavated at apex, lightly incised in some species, truncate or rounded in others, lobes rounded at sides, apices of epilobes barely projecting as a short tooth on each side; ligula short, wide, apex bisetose; paraglossae narrow, membranous, with apical halves free; palpi with penultimate segments bisetose, the apical ones slightly attenuate and subtruncate at apex, apparently glabrous, but actually with a few very short, very thin setae; maxillae sharp, hooked at apex, inwardly fringed with bristles, outer lobe jointed; maxillary palpi with last segment fusiform; antennae rather short, pubescent from and including segment 4. Prothorax with a setigerous pore near each basal angle and 1-3 such pores on each side in different species, in anterior half. Elytra with a basal margin, 9-striate, with a variable short scutellar stria between striae 1 and 2 and a setiferous puncture near base of 2 ; interstice 3 with $2-4$ 
punctures; inner plica present and well developed. Underside glabrous; prosternal process glabrous, margined at apex; metepisterna short, very little longer than wide; abdominal segments sulcate and with series of deep punctures across base. Legs normal except for the hind tibiae of one species; protarsi of male with first 3 segments strongly dilated, triangular; basal segments of tarsi glabrous on the upper side, not sulcate or carinate externally; segment 4 not emarginate; onychium with a few setae beneath; claws smooth. Aedeagus with the apical blade characteristically modified in the different species.

Genotype: Sierrobius smaragdinus Straneo (below)

Sierrobius could be considered a subgenus of the great genus Pterostichus (sensu lato), but the five new species I refer to it are very homogeneous generically, though very different from each other, and from other previously known species, and I prefer to consider it a distinct genus, confined to the Sierra Nevada de Santa Marta, Colombia.

\section{Key to the Species of Sierrobius}

1 (8) Size over $8 \mathrm{~mm}$.; hind angles of prothorax more or less blunt.

2 (3) Striae of elytra strongly but irregulary impressed; lateral margin of pronotum in anterior half always with 2-3 setae; aedeagus as in Fig. 3

smaragdinus n. sp.

3 (2) Striae of elytra either strongly but regularly impressed, or faint; lateral margin of prothorax in anterior half usually with a single seta.

4 (7) Elytra with all striae faint throughout, except that 2 and 3 are lightly impressed in one species and 7 is always rather deeply impressed; basal angles of prothorax wholly rounded.

5 (6) Size smaller (12 mm.) ; striae 2 and 3 slightly but distinctly impressed; extremity of stria 7 deeply and irregularly impressed, with two conspicuous setiferous punctures; aedeagus with apex strongly asymmetrical (Fig. 4). .bistriatus n. sp. 
6 (5) Size larger; all striae faint; aedeagus with apex nearly symmetrical (Fig. 5) laevigatus n. sp.

7 (4) All striae deeply and regularly impressed; basal angles of prothorax obtuse but well formed.

uniformis $\mathrm{n}$. sp.

8 (1) Size $8 \mathrm{~mm}$; hind angles of prothorax square.

parvulus n. sp.

Sierrobius smaragdinus, n. sp.

Head bright green; prothorax green with golden reflections; elytra green with bluish reflections chiefly at sides; mouth piceous black; femora brown with metallic reflections; underside slightly greenish; antennae brown; palpi blackish with apices ferrugineous. Length $12.8 \mathrm{~mm}$; width $4.1 \mathrm{~mm}$. Head smooth and shining; eyes moderate, temples short and little convex; frontal impressions very short and very little impressed; antennae moderately elongate, hardly reaching base of prothorax, with segments 4-11 pubescent. Prothorax subquadrate (3.1 by $3.8 \mathrm{~mm}$.), anteriorly a little emarginate, with sides very little rounded, nearly parallel at middle, briefly narrowed to apex (width $2.6 \mathrm{~mm}$.) and base (width $3 \mathrm{~mm}$.) ; anterior angles only a little prominent, rounded; basal ones a little obtuse, with their apices rounded; basal impressions foveiform, elongate, deep, and rather wide; spaces between them and lateral margins convex; side margins narrow, nearly linear, with two setigerous pores in anterior half $(\hat{o})$ or three $(q)$ and also the usual pore near each basal angle; base nearly impunctate, a little rugose at middle, slightly margined at sides; disc only a little convex; median line deep, abbreviated anteriorly and posteriorly. Elytra subparallel, convex (7.6 by $4.1 \mathrm{~mm}$.); sides slightly rounded behind base; shoulders rounded, without teeth; basal margin strong, nearly right; scutellar stria very short, with a large puncture near base; striae very irregular, only slightly impressed, punctate; interstices only slightly convex, irregular, third with 4 large punctures, of which the first is near the third stria, the others near the second; seventh interstice with two apical punctures; umbilicate series of 16 punctures; apical sinuation strong. 
Prosternum slightly depressed between coxae; pro-episterna smooth; metepisterna small, nearly as long as wide; prosternal process margined; abdominal segments sulcate and with series of coarse punctures across their bases; anal segment with one puncture each side ( $\hat{o}$ ) or with two ( $q$ ). Microsculpture of elytra rather indistinct. Aedeagus as shown in Fig. 3.

Holotype $\delta$ (Museum of Comparative Zoology, Type No. 28,426 ) and allotype o (my collection) from the northwestern Sierra Nevada de Santa Marta, Colombia, 12,000 ft., Feb. 11, 1929 (Darlington). ${ }^{1}$ The specimens were taken in the páramo zone above the forest line.

\section{Sierrobius bistriatus, n. sp.}

Head and prothorax metallic dark blue; elytra greenish blue with slight metallic reflections; underside brown with metallic reflections; legs, antennae, and mouth ferrugineous brown. Length $11.2 \mathrm{~mm}$.; width $3.7 \mathrm{~mm}$. Head as in preceding species. Prothorax with sides more rounded, more narrowed posteriorly; only one seta on each side in anterior half of lateral margin. Elytra shaped as in the preceding species, but with the shoulders more rounded; striae very faint excepting the third and fourth ones, which are very lightly impressed; third interstice with three large punctures, of which the first is near the third stria, the others near the second. Underside as in smaragdinus. Hind tibiae simple. Aedeagus of wholly different shape (Fig. 4.)

Holotype of (Museum of Comparative Zoology, Type No. 28,428 ) from the northwestern Sierra Nevada de Santa Marta, Colombia, 8-11,000 ft., Feb. 10-12, 1929 (Darlington). The type is unique. It comes from the highest ("temperate") moutain forest.

\section{Sierrobius laevigatus, n. sp.}

Upper surface metallic violaceous red with greenish reflections, lightly alutaceous, moderately shining; underside blackish; appendages brownish piceous. Length $16 \mathrm{~mm}$.;

${ }^{1}$ All specimens taken in the Sierra Nevada de Santa Marta by P. J. Darlington Jr. were collected along the trail that ascends the Sierra from Rio Frio. 
width $5.1 \mathrm{~mm}$. Head stouter than in the preceding species, with shorter mandibles and less convex eyes. Prothorax of nearly the same shape as in bistriatus but more elongate (4 by $4.5 \mathrm{~mm}$.), with a single seta on each side in the anterior half of the lateral margin as well as the usual one at each basal angle. Elytra smooth, striae all faint, not impressed (but ninth stria well impressed as usual); three punctures on each side in the third interstice; umbilicate series of 15 punctures. Underside as in the other species. Hind tibia with a stout tooth ventrally (Fig. 6). Elytral microsculpture very regular, isodiametric. Aedeagus with apex rather regular (Fig. 5).

Holotype of (Museum of Comparative Zoology, Type No. 28,425 ) from the northwestern Sierra Nevada de Santa Marta, Colombia, 4-8,000 ft., July 20, 1928 (Darlington). The type is unique. It was found on the ground in heavy "subtropical zone" forest.

\section{Sierrobius uniformis, n. sp.}

Brown; head, prothorax, and elytra without metallic reflections; scarcely shining, elytra alutaceous. Length 14 $\mathrm{mm}$.; width $4.7 \mathrm{~mm}$. Head as in preceding species, but with frontal impressions wide and deep, though short. Prothorax transverse ( 3 by $4.1 \mathrm{~mm}$.), with sides regularly and equally narrowed and rounded anteriorly and posteriorly; anterior margin distinctly emarginate; anterior angles little prominent, obtuse, well rounded; basal angles obtuse, with their apices scarcely blunted; basal impressions deep, rather elongate; spaces between them and lateral margins slightly impressed near base, as if there were poorly marked external basal impressions; basal margin vestigial, visible only at sides; lateral margin narrow, with a single puncture on each side in anterior half and the usual puncture at each basal angle; disc moderately convex, with median line rather deep, almost reaching base. Elytra convex, subparallel (8.1 by $4.7 \mathrm{~mm}$.) ; scutellar stria distinct, without basal pore; striae well impressed, regular; interstices rather convex, third with three or four dorsal punctures. Underside as in the other species of the genus; anal segment of $q$ with two 
punctures on each side. Hind tibiae normal. Male unknown.

Holotype $\&$ (Museum of Comparative Zoology, Type No. $28,427)$ from the northwestern Sierra Nevada de Santa Carta, Colombia, 12,000 ft., Feb. 11, 1929 (Darlington). The type is unique, and is from the páramo zone.

\section{Sierrobius parvulus, n. sp.}

Upper surface dark bronze; head and prothorax shining, elytra ( o ) alutaceous; antennae, legs, and palpi ferrugineous; underside brown. Length $7.9 \mathrm{~mm}$; ; width $2.7 \mathrm{~mm}$. Head robust; eyes small and little convex; temples half as long as the eyes; frontal impressions deep, parallel, moderately elongate. Prothorax elongate, subrectangular ( 2 by $2.2 \mathrm{~mm}$.), truncate anteriorly; sides moderately rounded and narrowed anteriorly, nearly straight and slightly convergent towards base; anterior angles not or very little prominent, rounded; posterior angles square, with their apices not rounded; basal impressions slightly impressed, spaces between them and lateral margins little convex; lateral margins narrow, with one puncture on each side in anterior half and the usual puncture at each posterior angle; base not margined at sides; disc only a little convex; median line nearly reaching base. Elytra oblong-ovate ( 4.3 by 2.7 mm.) ; shoulders slightly obtuse, each with a minute tooth; scutellar stria very short, without apical pore; striae moderate; interstices not convex, the third with two punctures of which the first is at $1 / 5$ and the other at $3 / 5$ of the length; apical sinuation slight. Underside as in the other species of the genus. Hind tibiae simple. Male unknown.

Holotype o (Museum of Comparative Zoology, Type No. $28,429)$ from the northwestern Sierra Nevada de Santa Marta, Colombia, 8-11,000 ft., Feb. 10-12, 1929 (Darlington). The type is unique, and is from the "temperate" forest zone.

\section{Pachyabaris, n. gen}

So closely allied to Abaris Dej., Abaridius Chaud., and Pseudabaris Chaud. that it is not necessary to give a full description. The peculiar characters of the new genus are; 
shape of prothorax, differing from species to species; third interstice of elytra with at least three conspicuous foveae; ventral segments deeply grooved and with series of large punctures across their bases; tarsal claws not pectinate; onychium with setae beneath. This genus is most closely allied to Pseudabaris, which too has the ventral segments grooved and the tarsal claws not pectinate, but the new genus differs from Pseudabaris in having the third interstice of the elytra tri- or quadri-foveolate.

Key to the Species of Pachyabaris

1 (4) Sides of prothorax strongly rounded and narrowed anteriorly and posteriorly.

2 (3) Prothorax strongly transverse, with anterior margin rather deeply emarginate, and with sides rounded to basal angles; shoulders squarer. darlingtoni n. sp.

3 (2) Prothorax less transverse, with anterior margin less emarginate, and with sides evidently subsinuate before base, so that the basal angles are less obtuse subcordata n. sp.

4 (1) Sides of prothorax not much rounded, nearly straight and parallel.

5 (6) Striae rather strongly impressed, regular. striolata n. sp.

6 (5) Striae slightly impressed or irregular; interstices nearly flat.

7 (8) Prothorax widest before middle, its sides nearly straight, slightly narrowed towards base, with hind angles nearly square; all dorsal elytral punctures near $3 \mathrm{rd}$ stria; size smaller $(6 \mathrm{~mm}$.) . minuta n. sp.

8 (7) Prothorax widest behind middle, its sides slightly but distinctly rounded towards base, with hind angles obtuse; only anterior dorsal elytral puncture near 3rd stria ;size large $(7.5 \mathrm{~mm}$.). laevis n. sp. 


\section{Pachyabaris darlingtoni, n. sp.}

Dark bronze, scarcely shining; underside brown; legs, antennae, and palpi ferrugineous brown. Length $8.6 \mathrm{~mm}$.; width $3.3 \mathrm{~mm}$. Head moderately elongate; eyes wide, moderately convex; frontal impressions very short and deep; antennae scarcely exceeding base of prothorax, with segments 4-11 pubescent. Prothorax transverse (2.1 by 2.9 $\mathrm{mm}$.) ; sides strongly and regularly rounded; anterior angles obtuse, prominent; anterior margin distinctly emarginate; hind angles very obtuse, rounded at tips (the hind angles are not rounded in the paratype) ; anterior width $1.7 \mathrm{~mm}$.; basal width $2.3 \mathrm{~mm}$. ; one basal impression each side, deep; spaces between the impressions and the lateral margins each with a slight depression reaching lateral margin near middle of length; lateral margins narrow, each with the two usual setae; base impunctate, depressed between basal impressions, straight; disc only a little convex, with median line short, moderate. Elytra oblong-ovate (4.7 by $3.3 \mathrm{~mm}$.); shoulders square; basal margin moderately incurved towards shoulders; scutellar stria rather long; striae deep, impunctate; interstices slightly convex; third interstice with four deep, distinct foveae, the first at basal $1 / 4$, near third stria, the others near second stria (the number of foveae varies from 3 to 4 ) ; apical sinuation very strong. Prosternum not sulcate, sometimes slightly depressed; prosternal process margined; metepisterna not longer than wide, sulcate along anterior and interior sides; abdominal segments transversely sulcate, with series of strong punctures in the sulci; anal with one ( $\delta$ ) or two ( $q$ ) setae each side. Hind tarsi with only first segment slightly sulcate externally. Aedeagus as in Fig. 7.

Holotype $\delta$ (Museum of Comparative Zoology, Type No. $28,433)$, allotype $\&$ (my collection), and one + paratype (M.C.Z.) all from the northwestern Sierra Nevada de Santa Marta, Colombia, 12,000 ft., Feb. 11, 1929 (Darlington), taken of course in the páramo zone. 
Pachyabaris subcordata, n. sp.

Color as in $P$. darlingtoni. Length $11.3 \mathrm{~mm}$.; width 3.9 $\mathrm{mm}$. Head as in darlingtoni. Prothorax same in shape but with sides briefly but distinctly subsinuate before base; length of prothorax 2.5, width 3.3, width of apex 2.5, width of base $2.5 \mathrm{~mm}$. Elytra with shoulders more rounded; basal margin very thick, straight, not incurved; striae deeper and with indistinct vestigial punctation; scutellar stria shorter. Male unknown.

Holotype $q$ (Museum of Comparative Zoology, Type No. 28,435) from northwestern Sierra Nevada de Santa Marta, Colombia, 12,000 ft., Feb. 11, 1929 (Darlington). The type is unique.

Pachyabaris striolata, n. sp.

Upper surface bronze, moderately shining; underside brown, with slight bronze reflections; antennae, palpi, and legs ferrugineous red. Length $7.7 \mathrm{~mm}$.; width $2.5 \mathrm{~mm}$. Head as in $P$. darlingtoni. Prothorax rectangular (1.9 by 2.2 $\mathrm{mm}$.$) ; sides slightly narrowed anteriorly, nearly parallel$ or very slightly narrowed towards base; anterior width 1.5 , basal width $2 \mathrm{~mm}$.; basal angles square, with tips not rounded; basal impressions narrow, rather deep; spaces between them and lateral margins moderately convex; lateral margins narrow, linear, each with the two usual pores; base nearly impunctate, not depressed between the impressions; disc little convex, with the median line moderately deep, reaching base. Elytra elongate (4.1 by $2.5 \mathrm{~mm}$.) ; shoulders square, each with a minute tooth; basal margin straight, not thick; striae moderately impressed; interstices nearly flat, third with a puncture at basal 1/4, near third stria and two more punctures behind middle near second stria; apical sinuation moderate. Underside as in the other species; metepisterna with a few indistinct punctures. Microsculpture of elytra not very distinct. Aedeagus as shown in Fig. 8.

Holotype $\delta$ (Museum of Comparative Zoology, Type No. $28,430)$, allotype $\&$ (coll. Straneo), and one $q$ paratype 
(M.C.Z.) all from the northwestern Sierra Nevada de Santa Marta, Colombia, 12,000 ft., Feb. 11, 1929 (Darlington), from the páramo zone.

Pachyabaris minuta, n. sp.

Upper surface rather dark bronze; antennae, legs, and palpi darker than in the other species of the genus. Length $6.1 \mathrm{~mm}$.; width $2.3 \mathrm{~mm}$. Prothorax subrectangular, shaped as in striolata (1.4 by $2 \mathrm{~mm}$.) ; basal width 1.7 , apical width $1.3 \mathrm{~mm}$. Elytra oblong (3.4 by $2.3 \mathrm{~mm}$.) ; shoulders each with a minute tooth; basal margin slightly sinuate, not thick; striae lightly impressed, with vestigial punctation; interstices almost flat, third with 3 or 4 large punctures, all near third stria; apical sinuation slight. Hind tarsi stouter than in any other species of the genus. Microsculpture of elytra and of base of prothorax distinct, isodiametric. Aedeagus as shown in Fig. 9.

Holotype of (Museum of Comparative Zoology, Type No. 28,434 ), allotype o (coll. Straneo), and two paratypes (o in M.C.Z., of in coll. Straneo) all from the south side of the Sierra Nevada de Santa Marta, Colombia, 8-11,000 ft. (T. D. Cabot).

\section{Pachyabaris laevis, n. sp.}

Upper surface as in preceding species; legs, antennae, and palpi reddish brown. Length $7.6 \mathrm{~mm}$.; width $2.9 \mathrm{~mm}$. Form stouter than in preceding species. Prothorax wide (2.1 by $2.7 \mathrm{~mm}$.) ; sides moderately narrowed anteriorly, very little so basally; anterior width 1.7, basal width $2.5 \mathrm{~mm}$.; basal angles obtuse, with tips moderately rounded; basal impressions faint, spaces between them and lateral margins convex; base narrowly margined at sides; disc little convex, with median line moderately impressed, subpunctate, not reaching base. Elytra convex, moderately elongate ( 4.1 by 2.9 mm.) ; shoulders nearly square, each with a minute tooth; scutellar stria variable; striae faint; interstices flat, third with 3 or 4 punctures, the anterior one near third stria, 
others usually near second stria. Underside as in the other species of the genus. Microsculpture of elytra fine, isodiametric. Hind tarsi more slender than in minuta. Aedeagus as shown in Fig. 10.

Holotype $\hat{o}$ (Museum of Comparative Zoology, Type No. 28,431), allotype ㅇ (coll. Straneo), and 8 paratypes (M.C.Z. and coll. Straneo) all from northwestern Sierra Nevada de Santa Marta, Colombia, 11-12000 ft., July 21, 1928 (Darlington), taken in the páramo zone.

\section{Pseudabaris montanus, n. $\mathrm{sp}$.}

As the species of this genus are very closely allied among themselves and not well characterized, I give only a short preliminary description of this new one. Color aeneous, a little greenish, elytra slightly cupreous; underside dark brown; legs reddish brown; antennae wholly ferrugineous. Length $6.6 \mathrm{~mm}$.; width $2.7 \mathrm{~mm}$. Prothorax with sides regularly rounded, only a little narrower at base than anteriorly ; base wholly impunctate, with the inner basal impression rather slightly impressed and the outer one very short, nearly evanescent; spaces between basal impressions and lateral margins not depressed. Elytra short and convex, rather strongly dilated behind shoulders, which are minutely dentate; scutellar stria rather long. Apex of aedeagus shown in Fig. 11.

Holotype $\hat{o}$ (Museum of Comparative Zoology, Type No. 28,432) and allotype o (coll. Straneo) from Rio Frio, south of Santa Marta at the foot of the Sierra Nevada, Colombia, May 15, 1928 (Darlington); and 4 paratypes from northwestern foothills of the Sierra Nevada de Santa Marta, Colombia, not above 3,000 ft., May 22, June 2, and June 17, 1928 (Darlington).

This new species differs from columbicus Chaud. by smaller size; prothorax narrowed toward base; and elytra shorter, more rounded behind shoulders.

\section{Marsyas minutus, n. sp.}

Whole upper surface more or less greenish or coppery bronze; underside and legs blackish brown; antennae, tarsi, 
and palpi ferrugineous. Length $10 \mathrm{~mm}$; width $3.4 \mathrm{~mm}$. Head robust, with neck a little constricted; eyes wide, moderately convex; frontal sulci narrow and elongate; antennae slender, reaching the base of the prothorax. Prothorax moderately elongate (2.4 by $2.8 \mathrm{~mm}$.); sides regularly rounded; anterior angles near neck, rounded; basal angles nearly square, their tips moderately rounded; basal sulci narrow and moderately elongate; disc smooth, little convex; median line little impressed anteriorly, deep between the basal sulci, nearly obsolete near base; base impunctate, margined at sides; lateral margins very narrow, linear. Elytra oblong, elongate (5.6 by $3.4 \mathrm{~mm}$.) ; sides little narrowed towards shoulders; latter rounded, not dentate; striae deep, lightly punctate; interstices convex; third interstice with three punctures, the first at basal $1 / 4$ near third stria, the others near second stria. Underside smooth, impunctate; metepisterna 1.5 times long as wide, sulcate along inner and anterior sides. Legs normal; onychium with fine setae beneath. Aedeagus as shown in Fig. 12.

Holotype $\hat{\alpha}$ (Museum of Comparative Zoology, Type No. 28,439), allotype of (coll. Straneo), and 14 paratypes (M. C.Z. and coll. Straneo) all from vicinity of Horqueta, Paraguay, January 21 and 27 and February 1 and 4, 1934 (A. Schulze).

This new species, because of the position of the dorsal punctures of the elytra, belongs in the group of $M$. viridiaeneus. It differs from $M$. bahiae Tschit. by the shape of the prothorax, which is considerably narrowed towards base, and by the color of the upper side.

\section{Genus Cynthidia Chaud.}

Five species belonging to this genus have been described. There are probably several undescribed species, but I can give only a preliminary description of one of them. I have not yet secured males of planodisca Perty and cancellata Brullé necessary for comparison with the other new ones. 
Key to the Species of Cynthidia

1 (8) Third interstice of elytra with 2 or 3 impressed punctures.

2 (5) Frontal furrows deep and irregularly wide, the space between them carinate at middle.

3 (4) Prothorax with two basal impressions of subequal depth on each side; aedeagus as figured (Fig. 13) . . . . . . . . . . . . . . . crocipes Perty

4 (3) Prothorax with only the inner basal foveae (spaces between latter and lateral margins flat or very slightly impressed); aedeagus as figured (Fig. 14) ............. majorina n. sp.

5 (2) Frontal furrows only moderately deep, not irregularly wide, the space between them regularly convex but not carinate at middle.

6 (7) Interstices of elytra flat; dorsal pores on third interstice more distinct; elytra more or less opaque; prothorax shorter; frontal sulci wider planodisca Perty

7 (6) Interstices of elytra subconvex; dorsal pores on third interstice less distinct; elytra not opaque; prothorax longer; frontal sulci narrower cancellata Brullé

8 (1) Third interstice of elytra with wide foveae.

9 (10) Elytra damasked.............. octocoela Chaud.

10 (9) Elytra not damasked........... foveata Chaud.

\section{Cynthidia majorina, n. sp.}

Very near $C$. crocipes. The new species differs from the latter as follows: head with a light, minute, oval fovea near middle of front, between frontal sulci; prothorax less narrowed anteriorly, without distinct external basal impressions; elytra with dorsal punctures more conspicuous. Length $11 \mathrm{~mm}$. Aedeagus with different apex (Fig. 13).

Holotype $\hat{\sigma}$ (Museum of Comparative Zoology, Type No. 28,424) and allotype o (coll. Straneo) from Mafra, Sta. 
Catharina, Brazil, $780 \mathrm{~m}$. (A. Maller) ; one ô paratype from $5 \mathrm{~km}$. south of Sta. Maria, Rio Grande do Sul, Brazil (Th. White) ; and one of from Villarica, Paraguay (F. Schade). A dark $q$ example from S. Bernardino (Paraguay) probably belongs to this species.

The specimens I have attributed to $C$. crocipes are from Paranà ( $q$, in my collection) ; Villarica, Paraguay (5 specimens in M.C.Z.) ; and S. Antonio (Paraguay) (3 specimens from Institut Fabre, through Prof. Porta, in my collection).

Explanation of Plate 1

1. Aedeagus of Tichonia orientalis n. sp. 2. Aedeagus of Loxandrus minimus n. sp. 3. Aedeagus of Sierrobius smaragdinus n. gen. et sp. 4. Aedeagus of Sierrobius bistriatus n. sp. 5. Aedeagus of Sierrobius laevigatus n. sp. 6. Hind tibia of Sierrobius laevigatus n. sp. 7. Aedeagus of Pachyabaris darlingtoni n. gen. et sp. 8. Aedeagus of Pachyabaris striolata n. sp. 9. Aedeagus of Pachyabaris minuta n. sp. 10. Aedeagus of Pachyabaris laevis n. sp. 11. Aedeagus of Pseudabaris montanus $\mathrm{n}$. sp. 12. Aedeagus of Marsyas minutus n. sp. 13. Aedeagus of Cynthidia crocipes Perty. 14. Aedeagus of Cynthidia majorina $\mathrm{n}$. sp. 


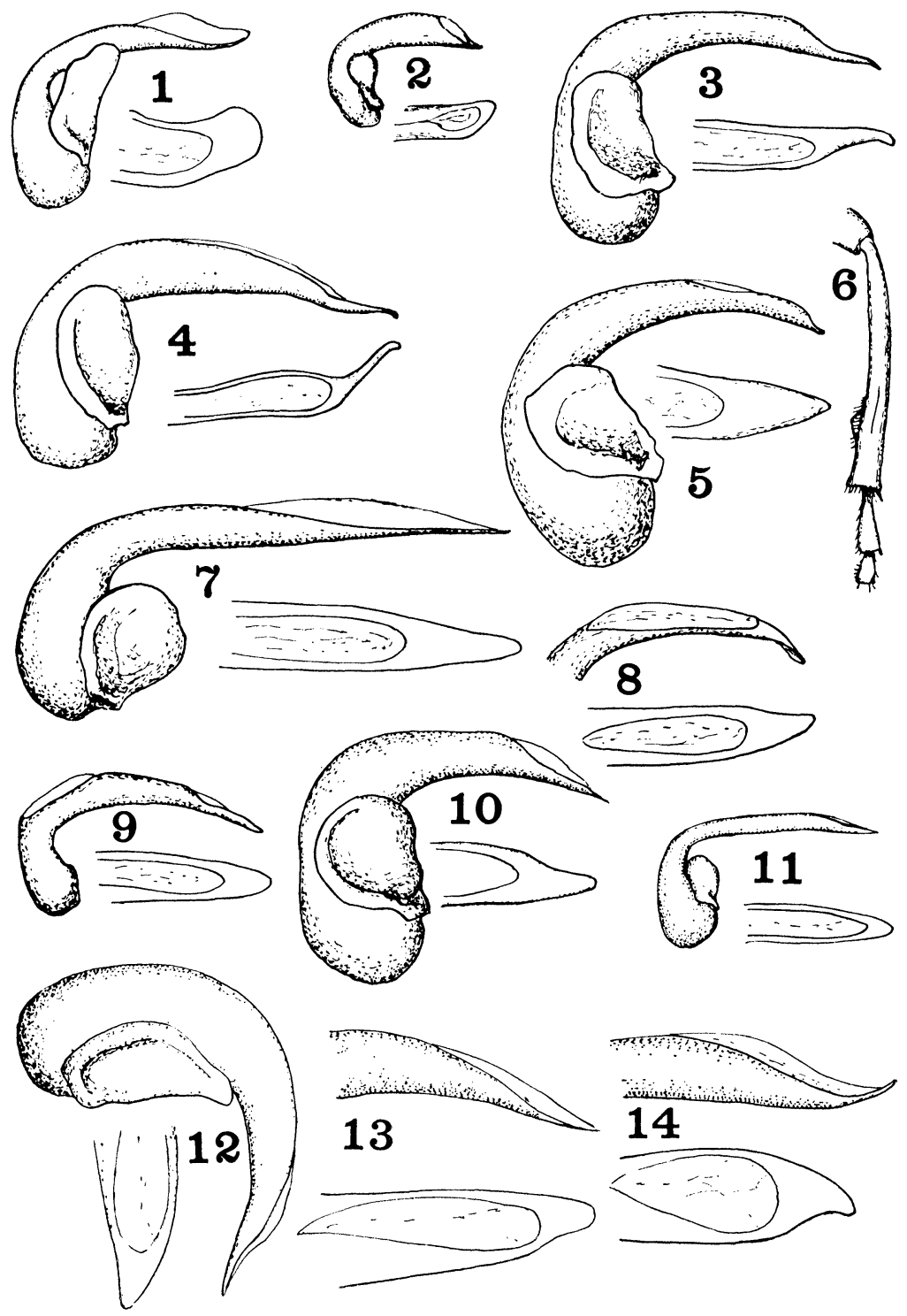

Straneo - PterostichinI 

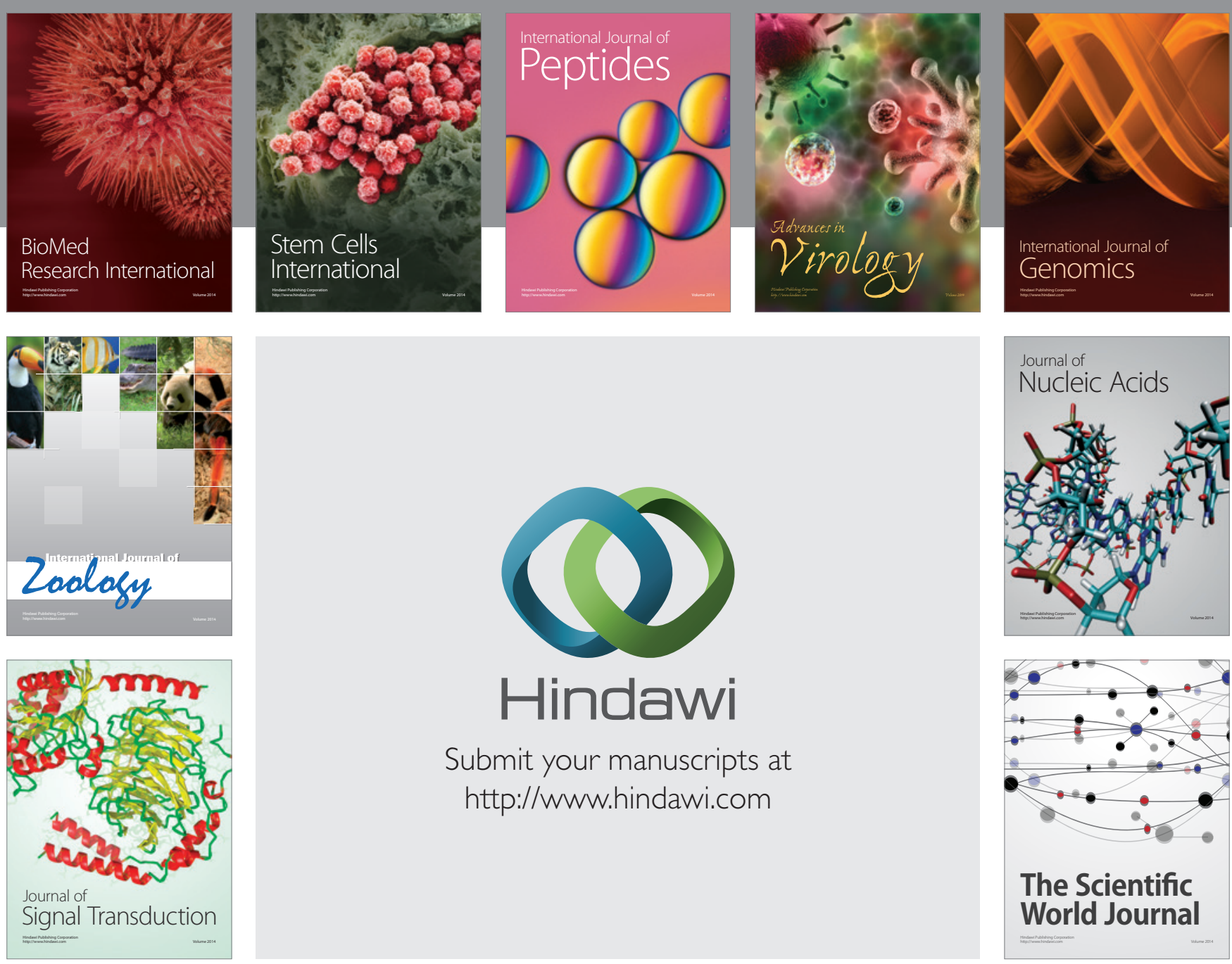

Submit your manuscripts at

http://www.hindawi.com
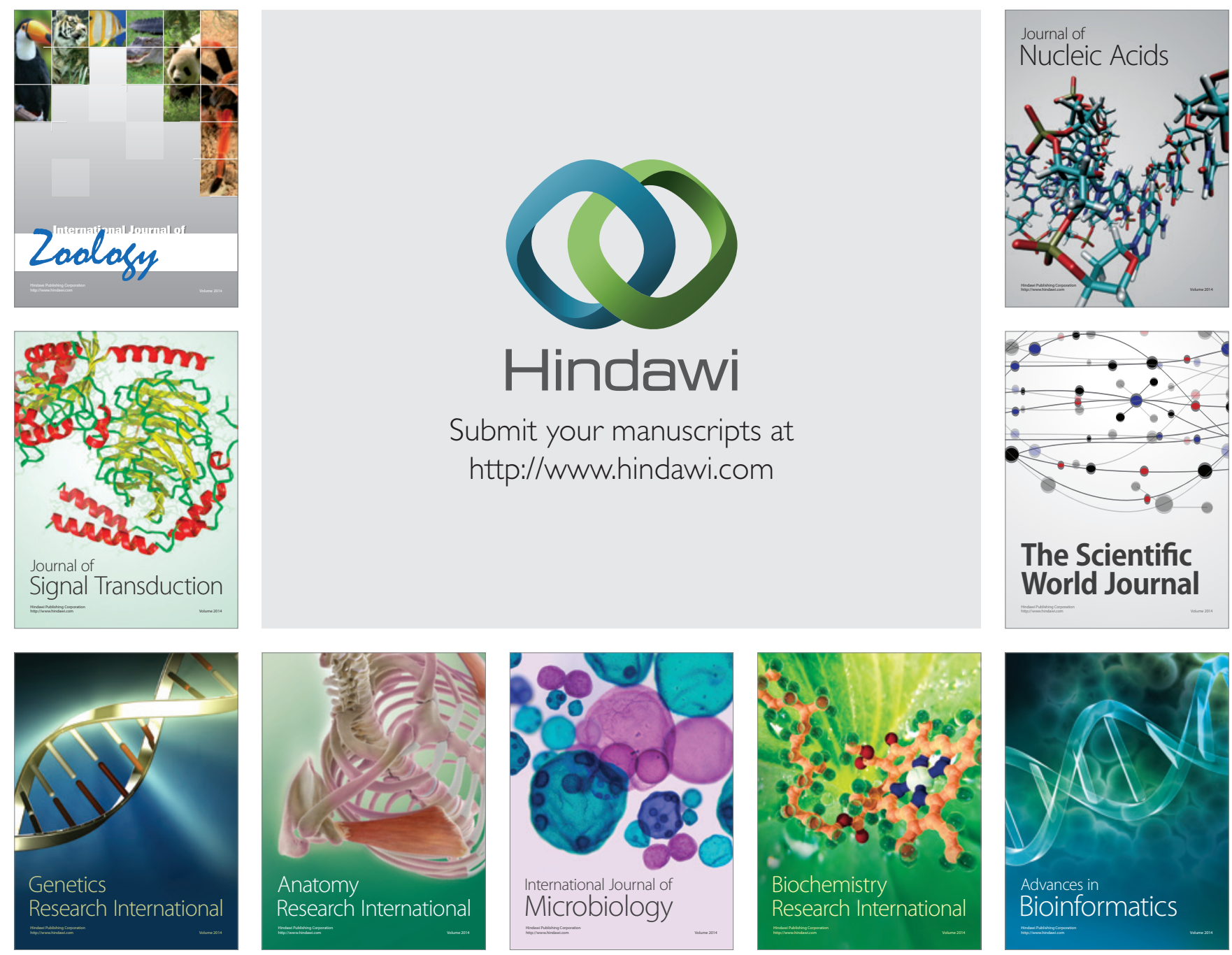

The Scientific World Journal
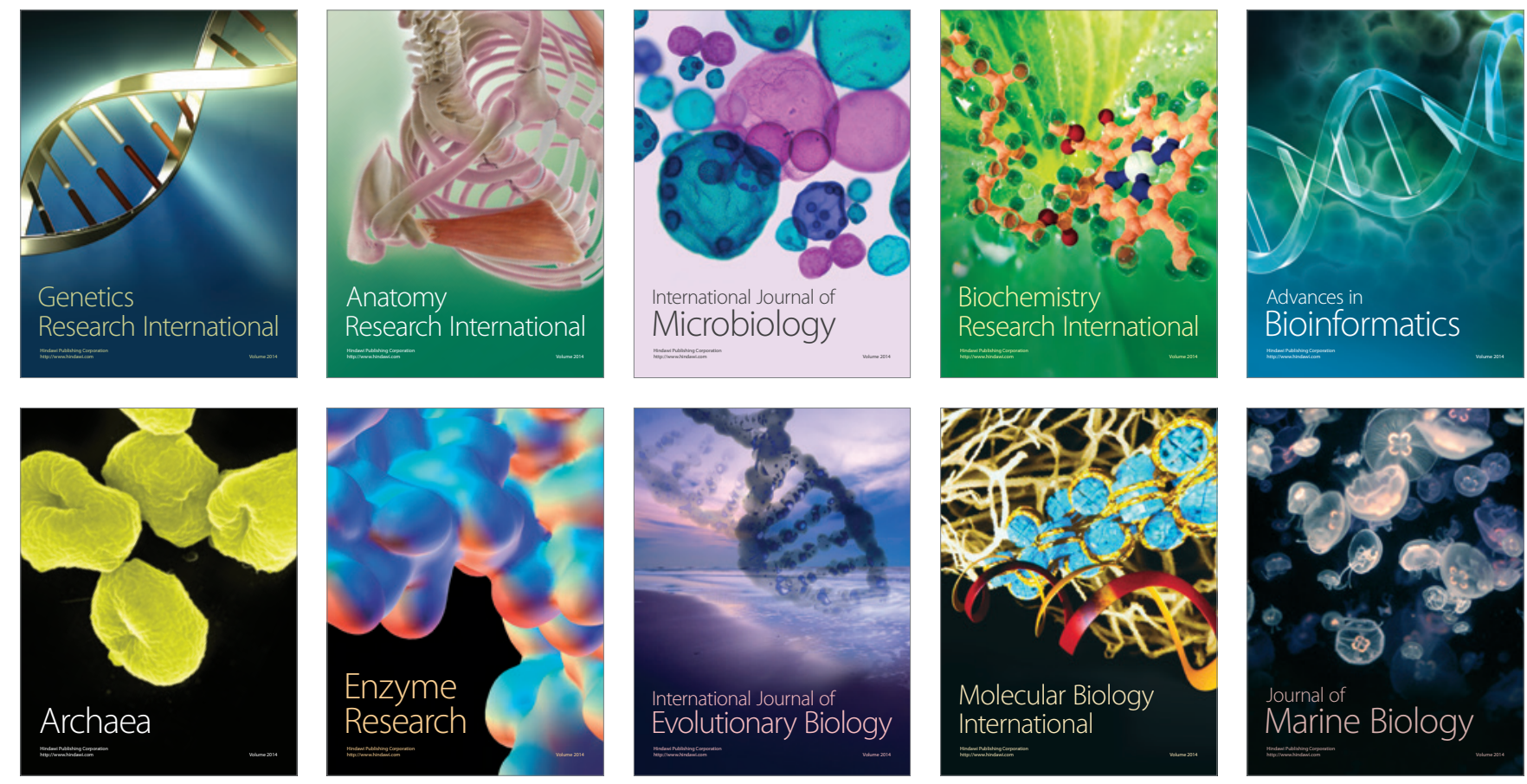